\title{
An Immunological Study of Avian, Viral and Bacterial Neuraminidase Based on Specific Inhibition of Enzyme by Antibody
}

\author{
By G. L. ADA AND PATRICIA E. LIND \\ Walter and Eliza Hall Institute of Medical Research, \\ Royal Melbourne Hospital Post Office, Victoria, Australia \\ AND W. G. LAVER \\ Department of Microbiology, Australian National University, \\ Canberra, Australia
}

(Received 27 December 1962)

\begin{abstract}
SUMMARY
Antisera were prepared to several strains of influenza virus (grown in the chick embryo), to purified Vibrio cholerae neuraminidase and to partially purified neuraminidase from chick chorioallantois. The ability of the antisera to inhibit the action of each enzyme on substrates of different molecular weight was tested. The substrates used and their molecular weights were sialyl lactose $(640)$, fetuin $(48,000)$ and ovine submaxillary gland mucin, OSM $\left(1 \times 10^{6}\right)$. Antiserum to $V$. cholerae and avian neuraminidase inhibited strongly the action of the homologous enzyme on each substrate. Antiserum to viral neuraminidase inhibited almost completely homologous action on fetuin and OSM but only partially the action on sialyl lactose. LEE influenza virus was grown in embryonated eggs and in cultures of calf kidney cells and from each preparation a soluble neuraminidase was isolated. Antiserum to the egggrown virus inhibited the enzyme of both viruses not only in the intact virus particle, but also after separation in the form of a soluble, low molecular weight product. There was little or no serological cross-reaction between any enzyme and heterologous antisera, with one exception. Antiserum to avian neuraminidase partially inhibited (fetuin, but not sialyl lactose, as substrate) the soluble enzyme derived from egg-grown LEE virus, but not from virus grown in cultures of calf kidney cells. It was concluded that the soluble enzyme prepared from LEE virus is a virus specific product but also carries some antigenic determinants characteristic of host specificity.
\end{abstract}

\section{INTRODUCTION}

The influenza virus particle displays at least four different biological activities (apart from infectivity), notably two distinct complement-fixing antigens, a haemagglutinin and the enzyme neuraminidase. The particle contains lipid, carbohydrate, ribonucleic acid (RNA) and protein. Terminal amino acid analysis suggests that there may be at least three different protein molecules in the particle (Laver, 1962, 1963a). Despite this complexity, this virus contains only about the same amount of RNA per particle as is present in many of the simpler plant and animal viruses, where it seems there is only one protein and this is of low molecular 
weight. This discrepancy may mean either that the small viruses use only a small proportion of their RNA to code the protein incorporated in the virus particle, or alternatively that in the influenza virus particle there is some component(s) whose structure is specified by the host cell rather than by the virus genome. We are interested in this latter possibility and the chance to investigate it with respect to one component arose following the demonstration that neuraminidase activity was present in vertebrate cells- the chorioallantois of the chick embryo (Ada \& Lind, 1961). If the avian enzyme is present in those cells which support virus growth, there is an obvious possibility that the host enzyme might be incorporated as the functional enzyme of the virus. To confirm or refute this hypothesis it was necessary to compare avian and viral neuraminidase with neuraminidase from other sources, such as bacteria, mammalian tissue, and from influenza virus grown in another host. Since all forms of neuraminidase have not been isolated in the purified form, this limited the ways in which the different enzymes could be compared. However, some properties such as their kinetics, sedimentation characteristics and some aspects of their serological behaviour could be studied with the partially purified preparations which were available. In this paper we present the results of a serological examination of avian, viral and Vibrio cholerae neuraminidases, based on the specific inhibition of their action on different substrates by antibody.

\section{METHODS}

Substrates. Sialyl lactose, fetuin and ovine submaxillary gland mucin (OSM) were prepared as described elsewhere (Ada, 1963).

Determination of enzyme activity. Enzyme estimations, with either purified or crude preparations, were carried out as described in detail elsewhere (Ada, 1963; Ada, French \& Lind, 1961). Enzyme activity is expressed as $\mu$ mole $N$-acetylneuraminic acid ( $N$-ANA) liberated $/ \mathrm{ml} . / \mathrm{min}$. One unit (u.) of enzyme is defined as that amount which catalyses the liberation of $1 \mu$ mole $N$-ANA/min. from sialyl lactose at $37^{\circ}$ at the $\mathrm{pH}$ value of optimum activity; for Vibrio cholerae neuraminidase, this was pH 5.6 (in tris + maleate buffer, $10^{-3} \mathrm{M}-\mathrm{Ca}^{2+}$; Ada et al. 1961); for virus, pH 5.8 (phosphate buffer; Ada, Cook \& Laver, unpublished) and for avian neuraminidase, $\mathrm{pH} 4.5$ (tris + maleate buffer, $\mathrm{pH} 4.5$; Ada, 1963). In view of the instability of the avian enzyme at $\mathrm{pH} \mathrm{4.5}$, estimations were carried out at $\mathrm{pH} \mathbf{5 . 9}$ (phosphate buffer) and the activity is calculated at this value. Smaller amounts of enzyme are described in terms of milli-units (m-u.).

Preparation of avian neuraminidase $(A N)$. Neuraminidase was purified from extracts of chorioallantoic membrane as described elsewhere (Ada, 1963). The product used contained about $1 \cdot 2$ units enzyme/mg. protein, which is about 50,000 -fold purer than a crude extract of membranes from 11-day embryos.

Preparation of mammalian neuraminidase $(M N)$. Mammary gland from a lactating rat (Carubelli, Trucco \& Caputto, 1962) was ground into phosphate buffer $(0 \cdot 1 \mathrm{M}$; pH 5.8) by using a Potter-Elvejehm type homogenizer. The extract was centrifuged $(80,000 \mathrm{~g} ; 30 \mathrm{~min}$.$) and the supernatant fluid (11.6 \mathrm{mg}$. protein $/ \mathrm{ml}$.$) used. This$ contained $1 \cdot 25 \mathrm{~m}-\mathrm{u}$. activity/mg. protein at $\mathrm{pH} \mathbf{5} \cdot 8$.

Preparation of viral neuraminidase (VN). Several strains of influenza virus were used at various stages during this work. Results obtained using the B strain LEE 
(Francis, 1940) and the A strains, BEL (Burnet, Beveridge, Bull \& Clarke, 1942) and PR 8 (Francis, 1934) are reported. Virus was grown in the allantoic cavity of chick embryos according to Beveridge \& Burnet (1946). LEE virus was purified by the method of Laver (1962); viruses PR 8 and BEL, concentrated from a red-cell eluate by two cycles of differential centrifugation (sedimentation, 38,000 $\mathrm{g} ; 30 \mathrm{~min}$.; clarification, $7000 \mathrm{~g} ; 10 \mathrm{~min}$.) were further purified by banding in a potassium tartrate density gradient (McCrea, Epstein \& Barry, 1961). LEE virus was also grown in calf kidney cells by the method of Lehmann-Grube (personal communication). Cells grown in a monolayer were inoculated with infected allantoic fluid at a multiplicity of about one. After incubation $\left(35^{\circ}, 4\right.$ days $)$ the released virus was harvested and purified by adsorption to and elution from red cells, followed by differential centrifugation.

Preparation of Vibrio cholerae neuraminidase (VCN). Neuraminidase from cultures of Vibrio cholerae was purified as described previously (Ada et al. 1961).

\section{Preparation of antisera}

Antiserum to avian neuraminidase $(A N)$. The preparation of purified enzyme contained about $2 \mathrm{mg}$. protein $/ \mathrm{ml}$. For the initial inoculation, enzyme solution was emulsified with an equal volume of complete Freund adjuvant (Difco). On day 1, $0.5 \mathrm{ml}$. was given intraperitoneally to two rabbits, $\mathbf{A}$ and $\mathbf{B}$. The rabbits were given $0 \cdot 5-0.75 \mathrm{ml}$. of avian neuraminidase intravenously on days $1,2,3,4,5,44,66$ and 108. Blood was taken before and after the last three injections. As judged from the degree of enzyme inhibition, the sera obtained, following the last two injections of antigen, were of equal potency. For the work reported in this paper serum from blood taken on days 114, 116 and 119 from rabbit A was used.

Antiserum to viral neuraminidase $(V N)$. The virus solution used in each case contained between 5000 and 10,000 agglutinating doses $/ 0 \cdot 25 \mathrm{ml}$. Emulsions were made by mixing equal quantities of antigen and adjuvant. On day 1, rabbits received $1 \mathrm{ml}$. virus emulsion intraperitoneally and $0.25 \mathrm{ml}$. of virus solution intravenously, and, on day 15, 0.25 ml. intravenously. Blood was taken on days 20, 22 and 24.

Antiserum to Vibrio cholerae neuraminidase (VCN). The enzyme solution contained $\mathbf{0 . 2} \mathrm{mg}$. protein $/ \mathrm{ml}$.; water-in-oil emulsions were made as above with Freund adjuvant. The rabbits received $1 \mathrm{ml}$. emulsion intraperitoneally on day 1 and $0.05 \mathrm{ml}$. intravenously on days $2,3,4$ and 5 . On day 32 , rabbits received $0.5 \mathrm{ml}$. intravenously and were bled on days $35,37,39$ and 42 .

In all cases, serum was taken from the clotted blood and heated (56 ${ }^{\circ}, 30 \mathrm{~min}$.). A fraction rich in $\gamma$-globulin was prepared from the serum (Pollock, 1956). The $\gamma$-globulin fractions (hereafter referred to as globulin) were stored either frozen or freeze dried. Sera were tested as described below.

Enzyme inhibition tests. These corresponded to constant antigen titrations. The reaction was carried out in total volume of $0.5 \mathrm{ml}$. The enzyme preparation $(0.35$ $\mathrm{ml}$.), at a suitable $\mathrm{pH}$ value and containing antibiotics when necessary, was added to $\mathbf{0} \cdot 10 \mathrm{ml}$. of the globulin preparation and the mixture stood at room temperature for $10 \mathrm{~min}$. The substrate $(0.05 \mathrm{ml}$.) was then added, the contents of the tube mixed and a $0.1 \mathrm{ml}$. sample taken. The tubes were incubated at $37^{\circ}$ and further $0.1 \mathrm{ml}$. samples taken at appropriate times. The liberated $N$-acetylneuraminic acid was estimated as described previously. Since the globulin preparations themselves 
contained substrate for neuraminidase, control solutions containing globulin prepared from preliminary bleed serum were also set up. Where purified preparations of enzyme were used, and sialyl lactose or fetuin as substrate, all dilutions of enzyme (VN, AN) were made in $0 \cdot 1 \mathrm{M}$-phosphate buffer $(\mathrm{pH} 5 \cdot 8)$ containing $0 \cdot 1 \%(\mathrm{w} / \mathrm{v})$ bovine plasma albumin (BPA; Armour laboratories) or, for VCN, 0.1 M-tris + maleate buffer ( $\mathrm{pH} 5 \cdot 6$ ) containing $10^{-3} \mathrm{M}-\mathrm{CaCl}_{2}$ and $0 \cdot 1 \%$ (w/v) BPA (Ada, 1963). BPA was not included when ovine submaxillary gland mucin was used as substrate.

\section{RESULTS}

\section{Effect of normal globulin on neuraminidase activity}

Although in most tests controls containing dilutions of normal globulin were set up, it is worth reporting briefly the results obtained with normal globulin prepared from many different sera. With two exceptions, normal globulin at a 1/10 dilution did not inhibit either avian or viral neuraminidase acting on sialyl lactose or fetuin. One preparation (dilution 1/10) inhibited (40\%) BEL virus but this effect was not observed at a 1/40 dilution. Another preparation inhibited avian (25\%) and viral neuraminidase $(14 \%$ ) at a $1 / 10$ dilution but less than $5 \%$ inhibition was seen at a $1 / 40$ dilution. Some preparations of globulin, when present in high concentration, showed a potentiating effect on enzyme activity. The reason for this is obscure. Globulin from rabbits hyperimmunized against bovine plasma albumin or diphtheria toxin did not inhibit either avian or viral neuraminidase.

\section{Inhibition of neuraminidases by homologous antisera}

Inhibition of avian neuraminidase $(A N)$. Fig. 1 shows the action of $A N$ on the three substrates in the presence of anti-AN globulin. Action on fetuin and OSM was inhibited by more than $95 \%$ and at least to $80 \%$ in the case of sialyl lactose. It is clear that the antiserum was not very potent however; this may have been due to the small amount of enzyme available for immunization, or to the nature of the enzyme.

Inhibition of Vibrio cholerae neuraminidase (VCN). Antiserum to VCN inhibited the action of the enzyme on each substrate (Fig. 2); action on fetuin and OSM was inhibited almost completely and a maximum of $90 \%$ inhibition of action on sialyl lactose was observed.

Inhibition of viral neuraminidase $(V N)$. Antisera to the three strains of influenza virus LEE, BEL and PR 8 which were grown in the chick embryo were tested for ability to inhibit the enzyme action of the corresponding virus on the three substrates. The results obtained with LEE virus are shown in Fig. 3; almost complete inhibition ( $>95 \%$ ) of enzyme action on fetuin and OSM occurred, whereas only slight inhibition of action on sialyl lactose was seen. The rate of action of LEE virus on OSM is so low that comparatively large amounts of virus had to be used in this test. Viruses BEL and PR 8 have little action on OSM but, when antisera to these viruses were tested as inhibitors of the action of corresponding virus on sialyl lactose and fetuin, similar patterns were observed: almost complete inhibition of action on fetuin and partial (20-50\%) inhibition of action on sialyl lactose.

Antiserum to LEE virus grown in eggs also inhibited the enzyme action of LEE virus grown in calf kidney cells. When tested in the presence of sialyl lactose or 
fetuin, this antiserum was active to the same dilution with virus grown in calf kidney cells as with virus grown in eggs. However, the action of calf kidney cell grown virus on sialyl lactose was inhibited by $40-50 \%$ compared with only $20 \%$ in the case of the egg-grown virus. An extract of cultured uninfected calf kidney cells had a low degree of neuraminidase activity.

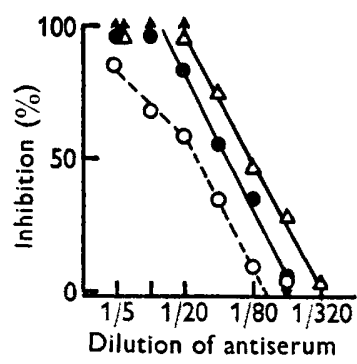

Fig. 1

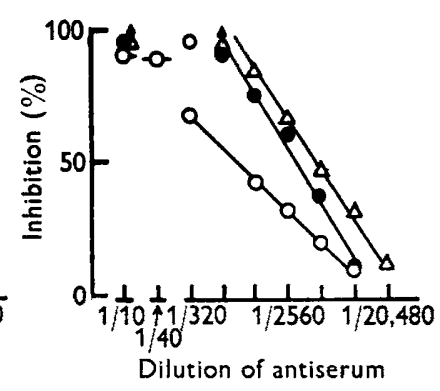

Fig. 2

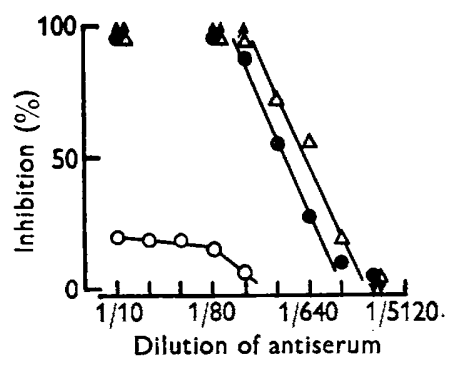

Fig. 3

Fig. 1. Inhibition of avian neuraminidase (AN) acting on sialyl lactose, fetuin or ovine submaxillary mucin (OSM) in the presence of anti-AN globulin. Each solution contained 2.4 m-u. enzyme. Time of incubation $180 \mathrm{~min}$. Sialyl lactose, $\bigcirc-\cdots \bigcirc$; fetuin, $-\cdots$; OSM, $\triangle-\triangle$.

Fig. 2. Inhibition of Vibrio cholerae neuraminidase (VCN) acting on sialyl lactose, fetuin or OSM in the presence of anti-VCN globulin. Each solution contained $2 \cdot 3 \mathrm{~m}-\mathrm{u}$. of enzyme. Times of incubation: for sialyl lactose, $120 \mathrm{~min}$.; for fetuin, $40 \mathrm{~min}$. ; for OSM, 30 min. Sialyl lactose, $\bigcirc-\bigcirc$; fetuin, - $O$; OSM, $\triangle-\triangle$.

Fig. 3. Inhibition of viral neuraminidase (whole LEE virus) acting on sialyl lactose, fetuin or OSM in the presence of autologous anti-viral globulin. Each solution contained $21 \mathrm{~m}$-u. of enzyme. Times of incubation; for sialyl lactose, $15 \mathrm{~min}$; for fetuin, $45 \mathrm{~min}$.; for OSM, $90 \mathrm{~min}$. Sialyl lactose, $\bigcirc-O$; fetuin, - ; OSM, $\triangle-\triangle$.

\section{Effect of heterologous antiserum on the activity of different neuraminidases}

In these cross-reaction tests, sialyl lactose and fetuin were used as substrates. Irrespective of the substrate, globulin fractions prepared against viral or Vibrio cholerae neuraminidase did not inhibit enzyme action of the heterologous antigens (VCN, VN, AN, MN). Globulin prepared against AN did not inhibit VCN or MN but there was slight but variable degree of inhibition of $\mathrm{VN}$ of avian origin (LEE, BEL) when fetuin, but not sialyl lactose, was used as substrate.

In the case of $\mathrm{CN}$ and MN compared with the other two enzymes, the lack of cross-reaction was expected since cross-reactions between enzymes have been found to depend not upon catalytic but on taxonomic factors (Cinader, 1957). The slight reaction of antiserum against $\mathrm{LEE}$ and BEL viruses was suggestive of some relationship between the two enzymes. If the viral and avian enzyme were related, one reason for the slight cross-reaction might be the inaccessability of some groups in the larger and more complex virus particle. Avian neuraminidase is small $\left(\mathrm{S}_{20}\right.$ about $3 \cdot 3$ ) whereas the intact virus has a sedimentation coefficient of $600-800 \mathrm{~S}$. The solution to the problem lay in finding methods for obtaining from the virus particle an enzymically-active fraction of low molecular weight. 


\section{Disruption of influenza virus}

Treatment with sodium dodecylsulphate. While this work was in progress, one of us (W.G.L.) developed a technique for the disruption of influenza virus by using the detergent sodium dodecylsulphate (SDS). When applied to the LEE strain of virus (with other strains tested, enzyme activity was lost), enzymically active fractions were obtained. These fractions were separated by electrophoresis on cellulose acetate, in a tris + boric acid + EDTA buffer ( $\mathrm{pH} \mathrm{8.9;} \mathrm{Aronsson} \mathrm{\&} \mathrm{Grönwall,} \mathrm{1957)} \mathrm{containing}$ $0.4 \%$ SDS; at least three bands of protein migrating towards the anode were observed. Most of the protein was in the two faster components (A, B); a third component $\mathrm{C}$ of low mobility contained about $6 \%$ of the total protein in the case of virus grown in eggs, and about $14 \%$ in the case of virus grown in calf kidney cells. Most of the enzyme activity was associated with component $\mathrm{C}$ although sometimes a trace was found in the slower of the main bands, B. The soluble enzyme from egggrown LEE virus was not retarded on a column of Sephadex G-75 and had a sedimentation coefficient of about $9 \mathrm{~S}$ (Laver, 1963b). We have examined other properties of components $\mathrm{C}$ and $\mathrm{B}$ and their serological behaviour is reported below.

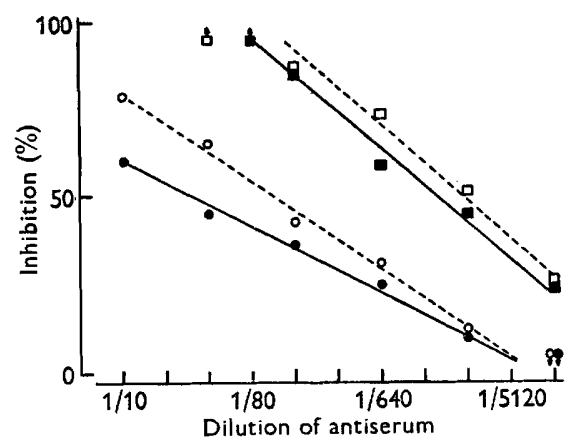

Fig. 4

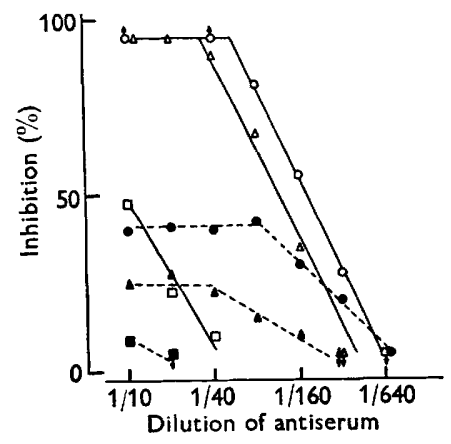

Fig. 5

Fig. 4. Inhibition by anti-LEE globulin of the action of the soluble enzyme from LEE virus grown in eggs and from LEE virus grown in calf kidney cells, on sialyl lactose and fetuin. Each solution contained about $2 \cdot 3 \mathrm{~m}-\mathrm{u}$. of enzyme. Time of incubation $120 \mathrm{~min}$. Soluble enzyme from virus (grown in chick embryo) acting on sialyl lactose - - on fetuin - - Soluble enzyme from LEE virus (grown in calf kidney cells) acting on sialyl lactose $\mathrm{O}-.-\mathrm{O}$; on fetuin $\square-\cdots \square$.

Fig. 5. Inhibition by anti-AN globulins of avian neuraminidase (AN) and of the soluble enzyme from egg-grown LEE virus acting on fetuin. The globulins were prepared from serum taken at different times during the immunization of rabbit A. Each solution contained 2.2 m-u. of AN or of the soluble enzyme from LEE virus. Time of incubation 120 min. Enzyme AN, bleed day $119 \bigcirc-O$; day $270 \square-\square$; day $283 \triangle-\triangle$. Soluble enzyme from LEE virus bleed day $119 \bullet \ldots . .-\bullet$; day $270 \quad \square \ldots . .-$; day $283 \triangle \ldots . .$.

\section{The serological properties of soluble enzyme from LEE virus}

Sialyl lactose and fetuin were used as substrates in these tests. Components B and $\mathrm{C}$ from egg-grown LEE virus were inhibited to the same extent by anti-LEE globulin; the inhibition curves of component $\mathrm{C}$ are shown in Fig. 4. Inhibition of action on fetuin was much the same as found with whole virus at this degree of activity, but there was a very marked increase of inhibition when sialyl lactose was used as the substrate. 
Component $\mathrm{C}$ from LEE virus grown in calf kidney cells was investigated; the inhibition curves obtained in the presence of anti-LEE globulin are also shown in Fig. 4. With fetuin as substrate, the anti-LEE globulin inhibited to about the same extent the soluble enzymes from LEE virus grown in eggs and from LEE virus grown in calf kidney cells. Inhibition of the action of the soluble enzyme on sialyl lactose was again substantially higher than was the case with the whole virus.

None of these soluble enzymes was inhibited by anti Vibrio cholerae neuraminidase globulin. The reactions with anti avian neuraminidase globulin are summarized in Table 1. Only component $\mathrm{C}$ from egg-grown LEE virus was appreciably inhibited (and only with fetuin as substrate); the extent of this inhibition is shown in Fig. 5 (curve --- ). Every preparation of the main enzyme fraction was inhibited by anti-avian neuraminidase globulin to an extent greater than that found with the parent preparation of virus. This inhibition varied from 30 to $50 \%$ at a globulin dilution of $1 / 10$ and was not shown at a dilution which varied from $1 / 80$ to $1 / 640$. The usual end point was $1 / 320$, which was also the end point of antibody titration of avian neuraminidase when this enzyme of equal activity (measured on fetuin) was used (see Fig. 5).

Table 1. Effect of antiserum to avian neuraminidase on the action of soluble enzymes derived from LEE virus on two substrates, sialyl lactose and fetuin

\begin{tabular}{|c|c|c|c|}
\hline \multirow{2}{*}{\multicolumn{2}{|c|}{ Soluble enzyme derived from }} & \multicolumn{2}{|c|}{ Substrate } \\
\hline & & Sinl-1 lotor & Wotur \\
\hline LEE virus grown in eggs & $\begin{array}{l}\text { Main fraction } \\
\text { Second fraction }\end{array}$ & $\begin{array}{l}\text { No inhibition } \\
\text { No inhibition }\end{array}$ & $\begin{array}{l}\text { Inhibition } \\
\text { Trace of inhibition }\end{array}$ \\
\hline $\begin{array}{l}\text { LEE virus grown in calf kidney } \\
\text { cells }\end{array}$ & Main fraction & No inhibition & No inhibition \\
\hline
\end{tabular}

Globulins prepared from sera taken at different stages of the immunization procedure was tested as inhibitor to soluble enzyme from egg-grown LEE and to avian neuraminidase. Rabbit A was bled on day 270 (previous bleed day 119), then re-injected intravenously with purified avian neuraminidase (9 units), and bled again on day 283. Globulin fractions from each antiserum were tested for their power to inhibit avian neuraminidase and the soluble enzyme from egg-grown LEE virus with fetuin as substrate. The results presented in Fig. 5 show that the ability of the anti-sera to inhibit avian neuraminidase and the soluble enzyme from LEE virus increased in the same order, namely, bleeds on days 270, 282 and 119.

\section{DISCUSSION}

Two main points have arisen from this investigation, namely, (1) the effect of size of substrate on the degree of inhibition of enzyme by homologous antibody, and (2) the isolation from the LEE strain of influenza virus of a soluble enzyme, which is inhibited not only by LEE antiserum but also by antiserum to avian neuraminidase. The three substrates used in this work differ in size and linkage. Sialyl lactose has a molecular weight of about 640 and the linkage is between $\mathrm{C}_{2}$ of $\mathrm{N}$-acetylneuraminic acid ( $N$-ANA) and $\mathrm{C}_{3}$ of galactose. Fetuin has a molecular weight of about 48,000 and the $N$-ANA is joined probably to galactose but the actual linkage is 
unknown. Ovine submaxillary gland mucin (OSM) has a molecular weight of about $1 \times 10^{6}$ (Gottschalk \& McKenzie, 1961); the linkage is between the $\mathrm{C}_{2}$ of $N$-ANA and $\mathrm{C}_{6}$ of $\mathrm{N}$-acetylgalactosamine. Although in many cases the rate of action of enzyme on OSM was very low or negligible, the other results indicate that inhibition studies with either fetuin or OSM as substrate gave similar results, i.e. the different linkages probably played only a minor role in this investigation. The different results obtained when sialyl lactose and fetuin were used as substrates might be due to size differences between the two molecules, since the linkage is to galactose in each case.

In the presence of homologous antibody, action of each enzyme on fetuin (and, when studied, on OSM) was almost completely inhibited. In Figs. 1-3, where the results of study of inhibition of avian, Vibrio cholerae and viral (egg-grown LEE virus) neuraminidases in the presence of autologous antisera are shown, the slopes of the inhibition curves are very similar; in each case a 16- to 32-fold decrease in antibody concentration in the mixture caused a change from almost complete to almost no inhibition of enzyme activity. In contrast, the slope of the inhibition curve of the soluble enzyme from egg-grown LEE virus, acting on fetuin in the presence of anti-LEE serum (Fig. 4) is less steep. The reason(s) for this is unknown. Autologous antiserum against the smaller enzymes (avian, $V$. cholerae) largely inhibited action against the small substrate, sialyl lactose, whereas similar action of the viral neuraminidase (Fig. 3) was only slightly inhibited. There are several possible reasons for this but until a more detailed analysis of each action is made, particularly taking into account the extent of enzyme-antibody aggregation, it would be fruitless to speculate.

The second finding, which is more relevant to our thesis, was that the soluble enzyme prepared from LEE virus by treatment with detergent reacted with antiserum to the parent virus particle and with antiserum to avian neuraminidase. The evidence for the specificity of the first reaction was the demonstration that virus grown in the chick embryo and in calf kidney cells, and the soluble enzymes derived from them, have common antigenic groups. The evidence for the specificity of the reaction with antiserum to avian neuraminidase may be summarized as follows. (1) Antiserum to avian neuraminidase does not inhibit Vibrio cholerae or mammalian tissue neuraminidases. (2) The ability of globulins prepared from serum taken at different times during the immunization of rabbit $A$ to inhibit the LEE virus soluble enzyme varied in the same order as their ability to inhibit avian neuraminidase. (3) The dilution of antiserum which just failed to inhibit the enzyme action was usually the same for the avian neuraminidase and for the viral soluble enzyme (Fig. 5). (4) The antiserum to avian neuraminidase did not inhibit the activity of the soluble enzyme derived from LEE virus grown in calf kidney cells. (5) No preparation of normal globulin appreciably inhibited the LEE virus soluble enzyme. Preliminary experiments with antiserum prepared against soluble enzyme from LEE virus grown in eggs show that such antiserum inhibits equally well the soluble enzyme isolated from LEE virus grown in either host but does not inhibit purified avian neuraminidase (fetuin as substrate). The evidence thus points strongly to the conclusion that the soluble enzyme in the virus particle is a virus-specific product. An unambiguous interpretation of the reaction of isolated viral neuraminidase with antiserum to avian neuraminidase is not possible. If we take the results at their face value we must conclude that the soluble neuraminidase from egg- 
grown LEE virus is associated with some antigenic determinants derived from the host but that these determinants, either because of their low concentration or qualitatively defective antigenicity, are unable to provoke the formation of detectable antibody on injection into rabbits.

This work was supported in part by a grant from the National Health and Medical Research Council, Canberra, Australia.

\section{REFERENCES}

ADA, G. L. \& LiND, P. E. (1961). Neuraminidase in the chorioallantois of the chick embryo. Nature, Lond. 190, 1169.

AdA, G. L. (1963). Purification and properties of avian neuraminidase. Biochim. biophys. Acta (in the press).

Ada, G. L., French, E. L. \& Lind, P. E. (1961). Purification and properties of neuraminidase from Vibrio cholerae. J. gen. Microbiol. 24, 409.

Aronsson, T. \& Grönwall, A. (1957). Improved separation of serum proteins in paper electrophoresis. A new electrophoresis buffer. Scand. J. clin. lab. Invest. 9, 338.

Burnet, F. M., Beveridge, W. I. B., Bull, D. R. \& Clarke, E. (1942). Investigations of an influenza epidemic in military camps in Victoria, May, 1942. Med. J. Austral. ii, 371.

Beveridge, W. I. B. \& Burnet, F. M. (1946). The cultivation of viruses and rickettsiae in the chick embryo. Spec. Rep. Ser. med. Res. Counc., Lond. no. 256. London: H.M. Stationery Office.

Carubelli, R., Trucco, R. E. \& Caputto, R. (1962). Neuraminidase activity in mammalian organs. Biochim. biophys. Acta, 60, 196.

Cinader, B. (1957). Antibodies against enzymes. Annu. Rev. Microbiol. 11, 371.

Francis, T. (1934). Transmission of influenza by filterable virus. Science, 80, 457 .

Francis, T. (1940). New type of virus from epidemic influenza. Science, 92, 405.

GotTschalk, A. \& McKenzie, H. A. (1961). Studies on mucoproteins. VIII. On the molecular size and shape of ovine submaxillary gland mucoprotein. Biochim. biophys. Acta, $54,226$.

LAvER, W. G. (1962). The structure of influenza viruses. 1. N-Terminal amino acid analyses. Virology, 18, 19.

Laver, W. G. $(1963 a)$. The structure of influenza viruses. 2. C-terminal amino acid analyses. Virology (in the press).

LAVER, W. G. $(1963 b)$. The structure of influenza viruses. 3. Separation of neuraminidase activity after disruption of an influenza virus with detergents. Virology (in the press).

McCrea, J. F., Epstein, R. S. \& Barry, W. H. (1961). Use of potassium tartrate for equilibrium density-gradient centrifugation of animal viruses. Nature, Lond. 189, 220.

Pollock, M. R. (1956). An immunological study of the constitutive and the penicillininduced penicillinases of Bacillus cereus, based on specific enzyme neutralization by antibody. J. gen. Microbiol. 14, 90. 